\author{
Anna ZAGAJEWSKA \\ Uniwersytet w Białymstoku \\ anka.zagajewska@o2.pl
}

\title{
TRUDNE SLOWA. WYBRANE PROBLEMY ORTOGRAFICZNE W PRAKTYCE PISARSKIEJ
}

Polski system ortograficzny, w ogólnej świadomości, uchodzi za szczególnie trudny, nie tylko dlatego, że pisownia niektórych słów nie odpowiada wymowie, lecz głównie ze względu na jej konwencjonalność. Skodyfikowana norma ortograficzna obejmuje wiele różnorodnych i skomplikowanych zaleceń pisowniowych. Na co dzień niejednemu użytkownikowi języka towarzyszą różne wątpliwości. „Tymczasem, jak dowiódł prof. Stanisław Urbańczyk („Język Polski”, XL, 1960), który porównał naszą ortografię z systemami ortograficznymi innych narodów: "polska ortografia zasługuje co najwyżej na stopień średnio trudnej, zwłaszcza dla tych, co się swobodnie posługują wymową kulturalną»" (WSOF 2001: X).

W świetle powyższego stwierdzenia zdecydowano sprawdzić, jakie trudności sprawia polska pisownia ludziom, którzy ze społecznego punktu widzenia powinni wykazywać ponadprzeciętne kompetencje $\mathrm{w}$ posługiwaniu się polszczyzną. Celem niniejszego artykułu jest wskazanie najtrudniejszych miejsc $\mathrm{w}$ polskiej ortografii oraz przyjrzenie się powodom występowania tych trudności. Materiał językowy do analizy wybrano po badaniach ankietowych studentów. Przebadano pięćdziesięciosześcioosobową grupę studentów drugiego roku filologii polskiej studiów pierwszego stopnia na Uniwersytecie w Białymstoku. Należy podkreślić, że na studiach polonistycznych - poza zajęciami specjalistycznymi - kwestiom ortograficznym z reguły nie poświęca się zbyt wiele uwagi, gdyż wychodzi się z założenia, że na filologię polską trafiają ludzie już o wyrobionych kompetencjach ortograficznych. 
W celu sprawdzenia poziomu trudności wybranych problemów ortograficznych wśród studentów przygotowano dziesięciozadaniową ankietę, w której każde zadanie poświęcono przeważnie jednemu zagadnieniu, np. pisowni z cząstką -by. Większość zadań dobrano pod kątem sprawdzenia znajomości zasady konwencjonalnej polskiej pisowni, z uwagi na to, że przysparza ona Polakom najwięcej trudności. Ponieważ przyjęto, że grupą badawczą będą ludzie, od których szczególnie tej poprawności ortograficznej oczekujemy, przy doborze zarówno reguł, jak i egzemplifikacji wyrazowych nie opierano się wyłącznie na tzw. ortografii szkolnej, czyli typowych przykładach zawierających $u / o, \dot{z} / r z$ czy $c h / h$, oraz tych najważniejszych, w większości znanych użytkownikom, zasadach polskiej pisowni, tylko na ortografii profesjonalnej (Karpowicz 2009: 59), tzn. dotyczącej powszechnie najtrudniejszych, czasem szczegółowych zagadnień. Zadania, które opracowano, odznaczały się zróżnicowanym stopniem trudności.

Dwiema najważniejszymi sferami uregulowanymi decyzją kodyfikatorów są: pisownia łączna albo rozdzielna oraz użycie wielkiej lub małej litery, dlatego też znaczna część ankiety badawczej obejmowała powyższe zagadnienia. Niniejszy artykuł traktuje o trudnościach polskiej ortografii w zakresie pisowni łącznej i rozdzielnej.

Za trudne pod względem ortograficznym uznano te wyrazy, na które poprawnej odpowiedzi udzieliło co najwyżej 50\% ankietowanych osób. Wyniki ankiety ilustruje tabela 1 . Problemy omawiane $\mathrm{w}$ artykule dotyczą pisowni wyrażeń złożonych, złożeń przymiotnikowych i rzeczownikowych, pisowni nazw miejscowych, cząstki by i partykuły nie, jak również pisowni przedrostków oraz wyrażeń przyimkowych.

W kontekście przedstawionych wyników warto zastanowić się nad istotą trudności pisowni tychże słów, nad powodami użycia takiej a nie innej formy wyrazu przez badanych.

Jak wynika z badań ankietowych, najmniej respondentów wykazuje się wiedzą na temat pisowni słowa ponaddwuipótmiesięczny w zdaniu: Wróciła z ponaddwuipótmiesięcznej podróży. Wyniki zbiorcze pisowni, którą uznawano za właściwą, ilustruje Tabela 2.

Co może być przyczyną tak znacznych studenckich rozterek pisowniowych? Od razu nasuwa się przypuszczenie, iż ankietowani nie dostrzegają w tymże połączeniu wyrazowym przymiotnika złożonego. Spróbujmy tę kwestię rozważyć jednak dokładniej, gdyż wydaje się, iż przyczyny studenckich wątpliwości ortograficznych mogą być też inne. 
TABELA 1. Wyrazy najtrudniejsze pod względem ortograficznym (wg wyników ankiety)

\begin{tabular}{|l|c|}
\hline \multicolumn{1}{|c|}{ trudne słowa } & $\begin{array}{c}\text { wartość } \\
\text { procentowa } \\
\text { poprawnych } \\
\text { odpowiedzi }\end{array}$ \\
\hline ponaddwuipółmiesięczny & $11 \%$ \\
Kolonia Ostrów & $16 \%$ \\
eksmąż & $23 \%$ \\
nicnierobienie & $27 \%$ \\
bobyśmy & $34 \%$ \\
chybabyśs & $36 \%$ \\
pomału & $39 \%$ \\
z powrotem & $39 \%$ \\
nieraz & $41 \%$ \\
na co dzień & $43 \%$ \\
nowo narodzony & $43 \%$ \\
znad & $45 \%$ \\
nie mały, ale... & $46 \%$ \\
równobrzmiący & $46 \%$ \\
można by & $48 \%$ \\
na razie & $50 \%$ \\
\hline
\end{tabular}

$\mathrm{Z}$ jednej strony nie wszystkie kompendia ortograficzne podają tego typu przykłady w części słownikowej. Sprawdzono następujące słowniki: SOJP PWN pod red. M. Szymczaka (1986), WSOJP pod red. A. Markowskiego (1999), NSOG pod red. I. Kamińskiej-Szmaj (2005), WSOF pod red. J. Podrackiego (2011), WSO PWN pod red. E. Polańskiego (2011). Tylko WSOF, oprócz typowej dla wszystkich słowników pisowni, np. ponadtysiącletni, dla innych również ponadmilionowy czy ponadwymiarowy, ponadroczny bądź ponadziemski, rejestruje dodatkowo pisownię wyrazu ponaddwuipółgodzinny, analogiczną do przykładu, z którym zderzyli się ankietowani, czyli ponaddwuipótmiesięczny.

$\mathrm{Z}$ drugiej strony, trudności można się doszukiwać w dotarciu do jednoznacznych reguł oraz w różnej interpretacji cząstki ponad. Sprawdzono trzy słowniki ortograficzne. WSOF $\mathrm{w}$ rozdziale dotyczącym pisowni przedrostków zawiera następującą informację: „W języku polskim 
TABELA 2. Odpowiedzi ankietowanych na pytanie o poprawną pisownię wyrazu ponaddwuipótmiesięczny

\begin{tabular}{|l|c|}
\hline \multicolumn{1}{|c|}{ Odpowiedzi } & Liczba \\
\hline ponad dwu i półmiesięczny; ponad dwu i pół miesięczny & 20 \\
ponad dwuipółmiesięczny; ponad dwu i półmiesięczny & 7 \\
brak odpowiedzi & 4 \\
ponad dwuipółmiesięczny; ponaddwuipółmiesięczny & 4 \\
ponad dwuipółmiesięczny; ponad dwu i pół miesięczny & 3 \\
ponad dwuipółmiesięczny & 3 \\
ponaddwuipółmiesięczny & 3 \\
ponad dwuipółmiesięczny; ponad dwu i pół miesięczny; & 3 \\
ponaddwuipółmiesięczny & 2 \\
ponad dwu i pół miesięczny & 2 \\
ponad dwuipółmiesięczny; ponad dwu i pół miesięczny; & \\
ponad dwu i półmiesięczny & 1 \\
ponad dwu i półmiesięczny; ponad dwu i pół miesięczny; & \\
ponaddwuipółmiesięczny & 1 \\
ponad dwuipółmiesięczny; ponad dwu i półmiesięczny; & \\
ponaddwuipółmiesięczny & \\
\hline
\end{tabular}

przedrostki zarówno rodzime, jak i obce piszemy łącznie z wyrazami pospolitymi". W licznej grupie przedrostków znajdziemy również interesujący nas prefiks ponad- oraz przykładową pisownię wyrazów ponadindywidualny, ponadprzeciętny i ponadklasowość. WSO PWN również zamieszcza tę samą regułę, z tym że rejestruje inne przykłady. WSOJP natomiast podaje, co do interesującego nas problemu, następujące zasady: „Piszemy łącznie polskie a) przedrostki, np. ponadplanowy, [...], ponadsiedemdziesięcioletni, ponadtysiącdziewięćsetpięćdziesięciokilometrowy; b) początki zrostów, np. ponadto (= dodatkowo). Natomiast rozdzielnie piszemy przyimki (przed rzeczownikami, przymiotnikami i zaimkami w przypadku innym niż mianownik oraz przed przysłówkami), np. ponad plan, ponad siedemdziesiat, [...], ponad to (się wzniosę)".

Biorąc pod uwagę wyłącznie słowniki ortograficzne, można by mówić o jednoznaczności zasad, które to uznają słowo ponad za przedrostek lub przyimek. Ale jak traktować inne słowniki, np. Inny słownik języka polskiego pod red. M. Bańki czy Słownik wyrazów trudnych i kłopotliwych 
M. Bańki, których treści nie pokrywają się ze słownikami ortograficznymi? M. Bańko, udzielając porad językowych na łamach poradni internetowej PWN, za poprawną uznaje pisownię ponaddwuipółmiesięczny, ale też ponad dwuipótmiesięczny. W swoim Słowniku wyrazów trudnych i kłopotliwych opowiada się za wariantywnością pisowni w zależności od funkcji wyrazu ponad, który może być przedrostkiem bądź partykułą, a oba znaczą 'więcej niż' (Bańko 2010: 231). Podaje, iż taką samą funkcję ma partykuła przeszło. ISJP notuje: „Słowo ponad umieszczamy przed składnikiem zdania określającym liczbę lub ilość, jeśli chcemy powiedzieć, że czegoś jest więcej niż informuje ten składnik". Za przykład daje m.in. Zamknięty został etap ponad dwudziestoletnich badań... "Ponad- tworzy przymiotniki określające coś, co przekracza granice czegoś, np. ponaddźzwiękowy, ponadnormatywny (wykraczający ponad normę)".

Natomiast Rada Języka Polskiego w 2003 r., odpowiadając na list korespondentki w sprawie pisowni przymiotników i przysłówków za pomocą cząstki ponad-, niezgodność, o której mowa, tłumaczy odmienną interpretacją cząstki ponad- wskazującą na przyimek bądź partykułę. Jeśli ponad występuje w wyrażeniach stanowiących podstawę słów np. panaddwuletni, to Rada Języka Polskiego opowiada się za uznaniem cząstki ponad- nie za partykułę, lecz przyimek, w uzasadnieniu podając, iż:

Partykuła jednak to wyraz, który jedynie modyfikuje treść zdania, nie zmienia zaś jego znaczenia. Dlatego trudno uznać słowo ponad np. w wyrażeniu ponad dwa lata za partykułę - nie modyfikuje ono sensu zdania, lecz go wyraźnie zmienia. Partykuły zaś w zasadzie wprowadzają jedynie element modalny, wskazują na stosunek nadawcy do treści zdania; por. To kosztowało aż sto złotych. - To kosztowało tylko sto złotych $\mathrm{w}$ stosunku do To kosztowało ponad sto złotych (http://www.rjp.pan.pl).

Zatem skoro brak zgody wśród samych językoznawców, trudno oczekiwać jednolitości pisowni u użytkowników.

Warto zastanowić się też nad kłopotliwym zapisem drugiej części wyrazu, czyli dwuipótmiesięczny. Większość badanych nie potraktowała go jako przymiotnika złożonego, zatem za właściwą uznano pisownię *dwu i pótmiesięczny oraz *dwu i pót miesięczny. Wydaje się, iż błędny zapis nie wynikał z refleksji ortograficznej, ale z przekonania, że tak się powinno ten wyraz zapisać. Ankietowani nie wykazują się wiedzą z zakresu pisowni liczebnika złożonego z kilku członów, notabene pisowni ujętej w regułach ortograficznych. Przypuszcza się, sądząc po łącznym zapisie słowa pótmiesięczny, że o ile pisownia liczebnika składającego się 
z dwóch członów nie budzi u części respondentów żadnych wątpliwości - wygląda dość „naturalnie”, to już składająca się z czterech jest dosyć sztuczna. Uznano zapewne, że to wyrazy samodzielne znaczeniowo, więc niewchodzące w skład złożenia.

Kolejnym trudnym do napisania wyrazem okazała się nazwa własna Kolonia Ostrów. Większość ankietowanych opowiadała się za pisownią z łącznikiem. Studenci ponadto zostali poproszeni o zweryfikowanie pisowni Jastrzębie-Zdrój. Zadziwiająco, wypadła ona zdecydowanie lepiej, aż $71 \%$ badanych uznało za właściwy zapis z łącznikiem. A z uwagi na słownikowe rozbieżności, o których dalej, mogło być inaczej.

Do wyjaśnienia potencjalnych przyczyn owych sprzeczności prześledzono ciągi hasłowe w poszczególnych słownikach. Zaczynając od SOJP: właściwa pisownia to Jastrzębie-Zdrój z łącznikiem, w WSO PWN również. Inaczej natomiast jest w przypadku WSOJP i WSOF. Tu, za właściwą uznaje się pisownię rozdzielną Jastrzębie Zdrój. Z czego wynikają te niezgodności? Otóż, pisownia nazw miejscowych była kilkukrotnie zmieniana. Rada Języka Polskiego wyjaśnia, że:

[...] pisownia typu Jastrzębie-Zdrój, Rabka-Zdrój - a więc z łącznikiem - co najmniej od okresu międzywojennego była jedyną pisownią, usankcjonowaną przez przepisy prawa. Powojenne wykazy nazw miejscowości (np. „Wykaz urzędowych nazw miejscowości w Polsce", Warszawa 1980-1982) zamieszczają dwuczłonowe nazwy rzeczownikowe $\mathrm{z}$ łącznikiem. Wykazy te, choćby „Wykaz urzędowych nazw miejscowości w Polsce”, zawierają kodyfikację prawną. Do połowy lat 90 . zgodne ze stanem prawnym były przepisy ortograficzne. Słowniki ortograficzne bowiem podawały następującą regułę: „nazwy miejscowe złożone z dwóch lub więcej rzeczowników oznaczające jednostkę administracyjną lub geograficzną piszemy z łącznikiem: Skarżysko-Kamienna, Bielsko-Biała, [...], Busko-Zdrój [...] (Słownik ortograficzny PWN, red. M Szymczak, wyd. V, Warszawa 1981, s. 106). W roku 1996 „Nowy słownik ortograficzny PWN" pod red. E. Polańskiego zmienia tę regułę, zalecając niestosowanie łącznika $w$ nazwach rzeczownikowych, których drugi człon ma charakter podrzędny wobec pierwszego. Zgodnie $\mathrm{z}$ tą zasadą właśnie Jastrzębie Zdrój należało pisać bez łącznika" (Komunikaty RJP nr 1(16)/2005 w: http://www.rjp.pan.pl).

\section{Czytamy dalej:}

Należy jednak podkreślić, że nigdy nie zostały uchylone przepisy prawne, zgodnie z którymi nazwy typu [...] Jastrzębie-Zdrój pisze się z łącznikiem. [...] Od roku 1996 panowała zatem rozbieżność między zasadami ortograficznymi a przepisami prawnymi (http://www.rjp.pan.pl). 
Dopiero w roku 2004 Rada Języka Polskiego postanowiła przywrócić pisownię sprzed 1996 r. Wolą mieszkańców było natomiast zachowanie przyjętej pisowni miasta Jastrzębie Zdrój bez łącznika. Ostatecznie jednak pozostał zapis z łącznikiem i widnieje on dziś w wykazie urzędowych nazw miejscowości i ich części.

W uchwale z 2004 r. Rada dodała jeszcze istotną informację:

Nie piszemy z łącznikiem nazw miejscowych, w których jeden z członów nazwy miejscowej (przymiotnik) pozostaje w związku zgody z głównym członem nazwy (rzeczownikiem), np.: Dąbrówka Nowa, Nowy Sącz [...], a także wtedy, kiedy pierwszym członem nazwy są wyrazy: Kolonia, Osada, Osiedle, np.: Kolonia Ostrów (jak Kolonia Ostrowska) [...] (http://www.rjp.pan.pl).

To dodatkowe odstępstwo od głównej zasady może być dzisiaj źródłem błędów ortograficznych, nie tylko opisywanej grupy badanych, lecz większości użytkowników języka. Przedstawiona analiza pokazuje też przyczyny wariantywności zapisu omówionych nazw miejscowych: rozbieżności słownikowe wynikające ze zmienności przepisów, brak zgodności między kodyfikacją prawną a kodyfikacją ortograficzną. Z. Saloni (2005: 81) pisze, że przyczyną może być też zbyt dokładna kodyfikacja.

$W$ podjętym temacie zmienności reguł ortograficznych nie można pominąć również zmian w zakresie pisowni typu eksmąż. Mimo iż pisownia wyrazów z przedrostkiem eks- bez łącznika obowiązuje od 1997 r., czyli już od siedemnastu lat, to przez wiele lat w słownikach ortograficznych dopuszczano jej wariantywność (eks-mąż a. eksmąż). Dopiero nowszy SO PWN już jej nie rejestruje. Poruszona kwestia może być pretekstem do dyskusji nad sposobem wprowadzania zmian w polskiej ortografii oraz świadomością użytkowników. Przecież nie każdy co kilka lat kupuje nowy słownik ortograficzny. Ponadto, jak zauważa E. Awramiuk (2013: 571), „(...) pojawia się wątpliwość dotycząca funkcji słownika. Czy słowniki ortograficzne przekazują ustalenia kodyfikatorów, czy dokonują kodyfikacji?"

Z analizy badanego materiału wynika, że owszem, nowa pisownia coraz bardziej się upowszechnia, lecz w świadomości badanych jest jeszcze głęboko zakorzeniona pisownia rozdzielna przedrostka eks (zob. wykres 1).

Następna kłopotliwa kwestia ortograficzna wymagająca głębszego zastanowienia to pisownia wyrazu nicnierobienie. Słowniki podają łączny zapis tegoż wyrazu, jednak w treści przepisów nie jest on ujęty. M. Bańko 
WYKRES 1. Odpowiedzi ankietowanych na pytanie o poprawną pisownię wyrazu eksmąż

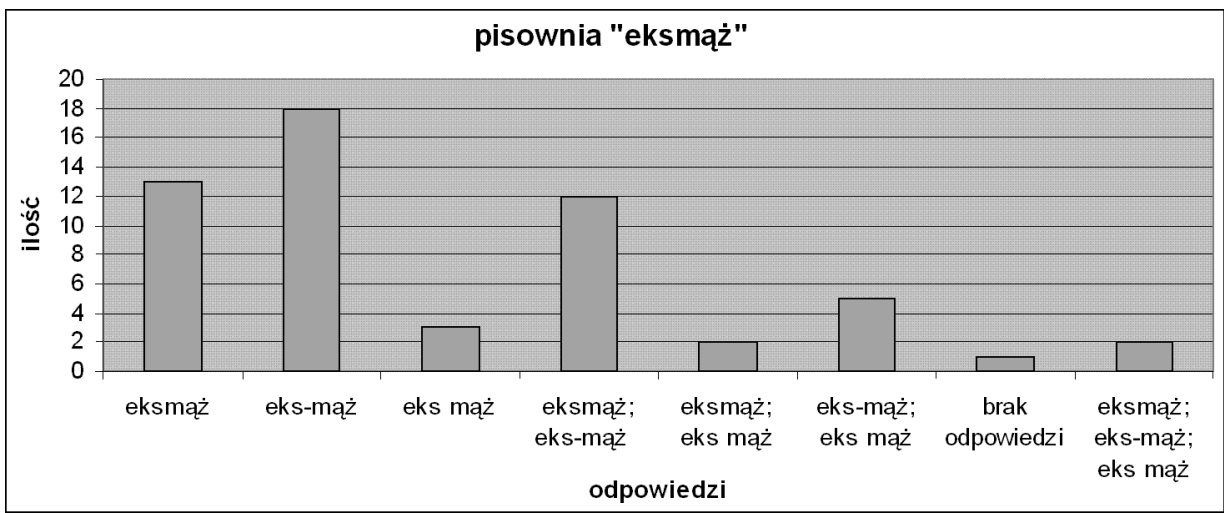

WYKRES 2. Odpowiedzi ankietowanych na pytanie o poprawną pisownię wyrazu nicnierobienie

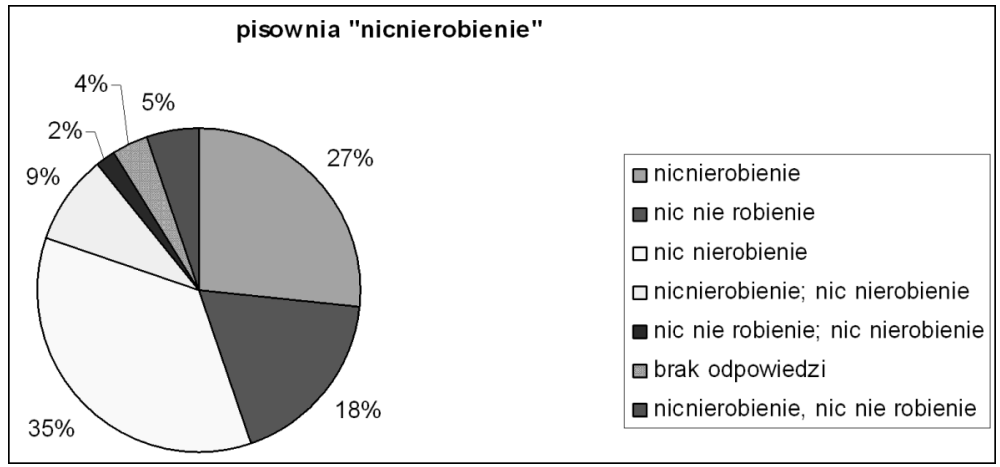

wręcz twierdzi, że taka pisownia jest nienormatywna i sugeruje, aby słowo nicnierobienie, poza „Dyktandem”, przytaczać w cudzysłowie lub z ubezpieczającym wykrzyknikiem (http://www.poradnia.pwn.pl). Ponieważ wśród odpowiedzi respondentów przeważał wariant z pisownią: *nic nierobienie oraz *nic nie robienie (zob. wykres 2), można by ów problem pisowniowy powiązać z pisownią nie z gerundiami. Mianowicie, badani mogą wykazywać się znajomością łącznej pisowni nie z rzeczownikami, jednak mimo wszystko popełniają błędy w pisowni zaprzeczonych rzeczowników odczasownikowych, co może mieć psychologiczne uzasadnienie. Otóż piszący czują „czasownikowość” odsłownika (gerun- 
dium), stosują więc do niego reguły czasownikowe. Za taką pisownią silnie też przemawia zwyczaj językowy. Użytkownicy języka w pisowni nie z rzeczownikami czynnościowymi widzą alternatywę: pisownię łączną lub rozłączną.

Przedmiotem dalszych rozważań jest kolejny umowny element naszej ortografii - łączna i rozdzielna pisownia cząstki by ze spójnikami i partykułami oraz wyrazami pełniącymi funkcję czasownika. Te zagadnienia sprawiły studentom największe trudności. Czy mogą wynikać z typowej nieznajomości zasad? Czy przyczyną jest niewłaściwa interpretacja statusu cząstki by czy klasyfikacja poprzedzającej ją części mowy? Respondenci zostali poproszeni o uzupełnienie następujących zdań:

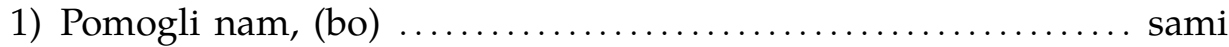
nie dali rady.

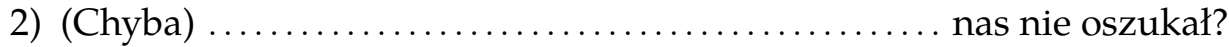

3) Pomyślę, jak (można) ................................. to zmienić.

W 1. i 2. przykładzie elementy bezpośrednio poprzedzające cząstkę by powinny zostać potraktowane kolejno za spójnik i partykułę. Idąc dalej tym tropem, użytkownik języka oba przykłady powinien zapisać łącznie. Owszem, pisownia ta nie była od początku jednolita, ale ostatecznie w takiej formie, w której funkcjonuje obecnie, została zatwierdzona wraz z reformą ortografii w 1936 r., więc już stosunkowo dawno (por. Jodłowski 1979: 115). Zatem nie byłoby na miejscu uznać, iż zmienność zasad wpłynęła na dzisiejsze błędy ankietowanych. W celu wyjaśnienia ich przyczyny prześledzono zasady WSOF, WSO PWN oraz poradnika ze słownikiem pt. Jak pisać? Razem czy osobno? (Polański, Skudrzykowa 2010). W WSOF w rozdziale dotyczącym pisowni łącznej wariantów cząstki -by napisano, że zakończenie -by piszemy łącznie z następującymi spójnikami..., i wymieniono ich 18. WSO PWN notuje, iż cząstkę -by i jej warianty pisze się łącznie z większością spójników, a zwłaszcza z następującymi..., i tu wynotowano ich 37. Natomiast w poradniku ze słownikiem Polańskiego i Skudrzykowej napisano, że partykułę by pisze się razem ze spójnikami..., i tu wymieniono ich 31.

Takie niejednoznaczne sytuacje wynikające z braku zgodności między wydawnictwami poprawnościowymi wprowadzają tylko użytkowników języka w niepotrzebne zakłopotanie. Jeśli przy opisie tej samej reguły w jednym kompendium używa się słów: 'większość' i 'zwłaszcza', z czego 
można wywnioskować, że nie wypisano wszystkich wskaźników zespolenia, a w pozostałych podaje się listy spójników, z których wynika, że są pełne, jednak różnią się one ilością, to nie dziwi fakt, że użytkownicy języka oczekują od językoznawców jednoznacznych rozstrzygnięć.

Omawiane błędy są również efektem rozejścia się uzusu z normą ortograficzną. Użytkownicy języka czasami mogą być świadomi zasad, ale zwyczaj językowy jest zbyt silny. "Jeżeli po danym spójniku użycie by jest częste i naturalne, piszący zazwyczaj stosują pisownię łączną (np. choćby, jeśliby); jeżeli jest rzadkie i nacechowane, przeważa pisownia rozłączna (np. bo by, albo by - por. Kosek, 1999)" (Saloni 2005: 82).

Od lat wielu użytkownikom języka sprawia kłopoty pisownia wyrażeń przyimkowych. Analiza badanego materiału również potwierdza te wątpliwości pisowniowe. Mimo iż dziś, w dobie Internetu, coraz częściej zwraca się uwagę właśnie na tego typu wykolejenia - istnieją przykładowo blogi na Facebooku poświęcone poprawnej polszczyźnie czy błędom językowym, gdzie zamieszczane są różnego rodzaju zdjęcia, wierszyki, historyjki z takimi błędami, a nawet koszulki $\mathrm{z}$ nadrukami - to mimo to nadal te wyrazy sprawiają wiele kłopotów użytkownikom języka, należąc tym samym do pospolitych błędów językowych.

W odniesieniu do błędnej wśród ankietowanych pisowni wyrażeń przyimkowych: pomatu, z powrotem, na co dzień, znad, na razie, i $\mathrm{w}$ tym wypadku uzus rozchodzi się ze skodyfikowaną normą. Nic więc dziwnego, że Polacy mają trudności z zapisem wskazanych form, ponieważ w polszczyźnie istnieje wiele skostniałych wyrażeń przyimkowych, uwarunkowanych dłuższą tradycją, o łącznej pisowni, np. pomału. Są to bardzo dawne połączenia. Nowsze wyrażenia przyimkowe natomiast piszemy rozdzielnie.

Analiza badanego materiału skłania również do refleksji nad trudnościami związanymi z rozdzielną pisownią zestawień, w których pierwszym składnikiem jest przysłówek, a drugim imiesłów odmienny czy przymiotnik określany przez ten przysłówek. Studenci wykazali wyraźną tendencję do łącznego zapisywania wyrażeń: nowo narodzony czy średnio zaawansowany. Możliwe, że źródłem problemu jest leksykalizacja niektórych słów, np. wysokoprocentowy, powstała niewątpliwie wskutek częstego użycia. Badana grupa napisała ten wyraz łącznie w 70\%. Niniejsza interpretacja nie znajduje jednak potwierdzenia w przypadku tendencji ankietowanych do rozdzielnej pisowni wyrazu równobrzmiący, choć o łącznej 
pisowni tegoż wyrazu zadecydowano już w 1957 r. Tu, zawiodła raczej świadomość badanych o drobnych zmianach w przepisach wprowadzonych w $1957 \mathrm{r}$.

Równie trudna okazała się pisownia partykuły nie z przysłówkiem odprzymiotnikowym w przykładzie: Nieraz ci o tym mówiłem. Przypuszczalnie powodem trudności jest niewyraźne zróżnicowanie pisowni nieraz/nie raz w słownikach, które wyjaśniane jest następująco: pisownia nieraz występuje w znaczeniu 'często', a nie raz znaczy 'nie jeden raz'. (Inne rozróżnienie: piszemy nieraz [z akcentem na nie-] (= często, ale: nie raz [z akcentem na raz], ale wiele razy). Takie uzasadnienie może budzić wśród użytkowników wątpliwości interpretacyjne, a w konsekwencji prowadzić do błędów ortograficznych.

Niełatwa była też pisownia nie z przymiotnikiem w konstrukcji ze spójnikiem przeciwstawnym ale $\mathrm{w}$ zdaniu: Zrobił się $z$ tego nie mały, ale duży kłopot. To wyjątkowa konstrukcja: nie X, ale $\mathrm{Y}$, będąca odstępstwem od podstawowej zasady, by nie z przymiotnikami pisać łącznie. To trudna sytuacja, w której piszących zawodzi poczucie jednolitości ortograficznej rozważanego przykładu - gdy mimo wyraźnych przesłanek przemawiających za pisownią łączną dany wyraz trzeba zapisać rozdzielnie.

Analiza współczesnych problemów ortograficznych w zakresie pisowni łącznej i rozdzielnej skłania do wniosku, iż wiele zagadnień ortograficznych, z którymi borykają się piszący, to rzecz głęboko dyskusyjna, kontrowersyjna i budząca też wątpliwości u językoznawców. Trudności ortograficzne wśród badanej grupy studentów nie wynikają wyłącznie z typowej nieznajomości skodyfikowanej normy. Słowa, których pisownia - jak wynika z przeprowadzonej ankiety - okazała się kłopotliwa, nie dotykają podstaw. Znaczne wątpliwości piszących wywołują natomiast jednostkowe rozstrzygnięcia dotyczące niektórych wyrazów czy przepisów, rozbieżności w zaleceniach wydawnictw poprawnościowych oraz niejednoznaczność w sposobie sformułowania przepisów. Współczesny uzus dowodzi, że niektóre reguły nie mają zastosowania nie tylko wśród przeciętnych użytkowników polszczyzny, ale nawet wśród młodych studentów polonistyki. Słowa trudne, sprawiające najwięcej kłopotów w praktyce pisarskiej, to między innymi, o czym niejednokrotnie pisze w swoim artykule Z. Saloni (2005), efekt stałej działalności kodyfikacyjnej, dążącej do objęcia drobiazgowych kwestii ortograficznych. 


\section{BIBLIOGRAFIA}

Awramiuk E., 2013, Pisownia polska w ostatnim siedemdziesięcioleciu, [w:] 70 lat wspótczesnej polszczyzny. Zjawiska, procesy, tendencje, red. A. Dunin-Dudkowska, A. Małyska, Wydawnictwo UMCS, Lublin, s. 563-579.

Bańko M., 2010, Słownik wyrazów trudnych i kłopotliwych PWN, Warszawa.

Jodłowski S., 1979, Losy polskiej ortografii, Warszawa.

Karpowicz T., 2009, Kultura języka polskiego. Wymowa, ortografia, interpunkcja, Warszawa.

Polański E., 2004, Reformy ortografii polskiej - wczoraj, dziś, jutro, „Biuletyn Polskiego Towarzystwa Językoznawczego" LX, s. 29-46.

Polański E., Skudrzykowa A., 2010, Jak pisać? Razem czy osobno? Poradnik ze słownikiem, Warszawa.

Saloni Z., 2005, O kodyfikacji polskiej ortografii historia i wspótczesność, "Nauka” PAN, nr 4, s. 71-96.

\section{SŁOWNIKI}

ISJP - Inny słownik języka polskiego PWN, pod red. M. Bańko, t. 2, Warszawa 2000: PWN.

NSOG - Nowy słownik ortograficzno-gramatyczny z zasadami ortografii $i$ interpunkcji, pod red. I. Kamińskiej-Szmaj, Warszawa 2005: Wydawnictwo Europa.

SOJP PWN - Stownik ortograficzny języka polskiego, pod red. M. Szymczaka, wyd. XII, Warszawa 1986: PWN.

USJP - Uniwersalny słownik języka polskiego, pod red. S. Dubisza, t. 3, Warszawa 2003: PWN.

WSOF - Wielki słownik ortograficzno-fleksyjny, pod red. J. Podrackiego, Warszawa 2003: Świat Książki.

WSOJP - Wielki słownik ortograficzny jezzyka polskiego, pod red. A. Markowskiego, Warszawa 1999: Wilga.

WSO PWN - Wielki stownik ortograficzny PWN z zasadami pisowni i interpunkcji, pod red. E. Polańskiego, Warszawa 2011: PWN.

\section{ŹRÓDŁA ONLINE}

so.pwn.pl: Wielki słownik ortograficzny PWN.

www.rjp.pan.pl: Rada Języka Polskiego.

https://portalwiedzy.pan.pl/images/stories/pliki/publikacje/nauka/2005/04/

N_405_04_Saloni.pdf. 


\section{DIFFICULT WORDS. \\ SELECTED SPELLING PROBLEMS IN THE ART OF WRITING}

\section{Summary}

This article depicts contemporary spelling doubts encountered by Polish Philology students as far as unhyphenated and hyphenated spelling is concerned. The linguistic material to be analyzed is a part of the major survey research. The purpose of the work is, among others, to provide an answer to the question which parts of codified spelling norms do not correspond to the spelling customs of young Polish philologists, and attempt to find the source of these difficulties.

Key words: spelling dificulties, spelling dictionary, spelling habits 